\title{
Correction: Introduction of an online programme for the specialty referrals combined with an outlier patient manager
}

Marinopoulos G. Introduction of an online programme for the specialty referrals combined with an outlier patient manager. BMJ Leader 2017;1:A21 doi:10.1136/leader-2017-FMLM.47.

Two additional authors have been added and updated online.

The order of the authors is now: Georgios Marinopoulos, Derrick GY Chieng, Damien Lynch.

(C) Article author(s) (or their employer(s) unless otherwise stated in the text of the article) [year]. All rights reserved. No commercial use is permitted unless otherwise expressly granted.

BMJ Leader 2018;2:49. doi:10.1136/leader-2017-FMLM.47corr1

A) Check for updates 